\title{
Carlos Drummond de Andrade: da cultura impressa às mídias digitais
}

\author{
Janeide Santos* \\ Elizabeth Gonzaga de Lima**
}

\begin{abstract}
Resumo
Nas últimas décadas, o mundo passou por inúmeras mudanças sociais e epistemológicas provocadas especialmente pelo desenvolvimento tecnológico que transmudou as formas de produção do conhecimento e acesso aos bens de consumo. Os modos de leitura de textos literários também foram influenciados, pois, se a leitura até a década de 1980 ancorava-se no livro impresso, jornais e revistas, na atualidade, observa-se um crescente uso de dispositivos digitais como computadores, tablets, smartphones para leitura. Os artefatos tecnológicos não apenas modificaram as formas de ler e escrever, como possibilitaram a descoberta da leitura por pessoas distantes das bibliotecas, livrarias ou bancas de revistas. Com a mobilidade promovida pela internet, a produção literária nos meios digitais tem ganhado força e vitalidade, ao mesmo tempo que textos produzidos no impresso passam a migrar para o ambiente virtual. $\mathrm{O}$ texto poético acompanha esse movimento, a exemplo da produção poética de Carlos Drummond de Andrade, surgida entre os anos 1920 e 1980 e que tem sido amplamente difundida e acessada nas mídias digitais disponíveis. A proposta deste trabalho é analisar o trânsito da poesia de Drummond, escrita inicialmente no suporte livro, mas que hoje tem ocupado grande espaço e mostrado intensa adesão e circulação no ciberespaço, em redes sociais, sites e blogs dedicados ao autor, o que tem
\end{abstract}

\footnotetext{
* Secretaria do Estado da Educação da Bahia. Mestrado em Estudo de Linguagens (UNEB). Professora da Educação Básica. ORCID: https://orcid.org/0000-0001-8676-4703.

* Universidade do Estado da Bahia (UNEB). Doutorado em Teoria e História Literária (UNICAMP). Pós-doutoramento no Programa de Literatura, Cultura e Contemporaneidade da PUC-Rio. Professora Titular do Programa de Pós-Graduação de Estudo de Linguagens e do Curso de Letras Vernáculas (DCH1).ORCID: https://orcid.org/0000-0002-3877-3776.
} 
garantido não só que sua obra se torne cada vez mais viva e vibrante, como também a atualização de seu público leitor.

Palavras-chave: Drummond. Cultura impressa. Mídia digital. Leitor.

\title{
Carlos Drummond de Andrade: From culture printed to digital media
}

\begin{abstract}
In the last few decades, the world has undergone countless social and epistemological changes caused especially by technological development which has transformed the forms of knowledge production and the access to consumer goods. The ways of reading literary texts were also influenced, because if reading until the 1980 s took place through the printed book, newspapers and magazines, nowadays there is a growing use of digital devices such as computers, tablets or smartphones for reading. Technological artifacts not only changed the ways of reading and writing, but also made it possible for people who were far from libraries, bookstores or magazine stands to discover reading. With the mobility promoted by internet, literary production in digital media has gained strength and vitality, at the same time that printed texts are migrating to the virtual environment. The poetic text also follows this movement, like Carlos Drummond de Andrade's poetic production produced between the 1920s and 1980s, and which has been widely disseminated and accessed through the available digital media. The purpose of this work is to analyze the transit of Drummond's poetry, initially written on physical books, but which today has occupied a large space, adhesion and circulation in cyberspace, on pages, websites, blogs dedicated to the author, which has guaranteed not only that his
\end{abstract}


work becomes more alive and vibrant, but also the update of his reading public.

Keywords: Drummond. Culture printed. Digital media. Reader.

Recebido em: 28/09/2021 // Aceito em: 18/12/2021. 


\section{Considerações Iniciais}

A produção, difusão e acesso ao texto poético transmudam conforme o tempo. A relação do leitor com o texto também passa por importantes modificações quando mudam os suportes e as formas de acessos a ele. A fim de compreender a relação do webleitor ${ }^{1}$ com os poemas de Drummond nas redes sociais digitais, faz-se necessário entender que a poesia acompanha a história da sociedade humana e, consequentemente, também faz uso dos novos suportes de produção e difusão de literatura acompanhando as constantes transformações das sociedades.

Em uma era em que as relações são mediadas pela tecnologia, assiste-se à transposição ${ }^{2}$ de textos já publicados em suporte de papel para o virtual e à criação de um novo fazer poético que emerge das mídias digitais. Ambos os movimentos são muito instigantes e demandam atenção; no entanto, optou-se por examinar a transposição para o digital de poemas já publicados no suporte papel. No caso da produção poética de Drummond, sua poesia já inscrita e consolidada no papel passou a ganhar cada vez mais espaço nos meios digitais por meio dos leitores que fazem a poesia drummondiana circular no mundo virtual nos diversos suportes disponíveis. Esse movimento revela o protagonismo do leitor diante das novas possibilidades interativas e colaborativas das plataformas de comunicação, fazendo emergir um novo cenário de leitores, autores e mediadores que disputam espaço e

1 Consideramos webleitores os sujeitos que realizam as suas leituras em telas de computadores, tablets ou smartphones. O termo "webleitor" é facilmente encontrado em textos acadêmicos disponíveis na internet e, sobretudo, no ambiente jornalístico, onde se utilizam também termos como "webjornal", "webjornalismo". Canavilhas (2001) defende o uso da denominação "webleitor" para indicar que o receptor não é apenas um leitor, telespectador ou ouvinte.

2 A transposição ou tradução de um texto literário para outro tipo de suporte ainda levanta muita discussão em função do papel que o livro ocupou e ainda ocupa como uma espécie de suporte legítimo de difusão do texto literário. Marcelo Spalding (2012, p. 19) esclarece que "o que está por trás desse apego ao livro é muito mais do que uma identificação ancestral com um objeto que atravessou milênios mais ou menos com o mesmo formato, e sim uma errônea percepção de que livro e literatura são uma entidade única, sendo um incapaz de sobreviver sem o outro [...]". 
reinventam papéis. Dessa maneira, o acesso ao texto, sua leitura e interpretação, leva o leitor a atualizá-lo e, ao levá-lo para as redes sociais, a desterritorializá-lo.

$\mathrm{O}$ desenvolvimento tecnológico na contemporaneidade possibilitou o acesso aos bens culturais a partir dos meios digitais. No caso da literatura, o processo de digitalização é irreversível, uma vez que as tecnologias já permeiam o cotidiano das pessoas. Todavia, a despeito de resistências aos meios digitais e/ou tecnológicos, vistos como ameaça inclusive à literatura, o que se observa é que esses meios também podem ser explorados pelo texto literário:

A Internet não põe a literatura em risco visto que, assim como o cinema e a televisão, ela é um meio que, de uma forma ou de outra, está recuperando para as diferentes telas os autores clássicos da literatura universal, levando para o público um pouco mais do que simplesmente textos, independentemente da idade desse público. (STEINER, 2002, p. 36).

Levando em consideração a relevância dos diversos suportes de circulação textual e a importância de Carlos Drummond de Andrade para a literatura brasileira, esse trabalho examina a dinâmica do movimento do texto poético da cultura impressa à mídia digital a partir da poesia de Drummond. A relação do poeta com os desafios apresentados pela sociedade aproxima seu texto do grande público e faz dele um dos maiores representantes da poesia brasileira do século XX. Sendo assim, não é surpresa que desde a primeira obra poética, Alguma poesia, em 1930, o escritor tenha seduzido gerações de leitores especializados em textos literários, usuários ou não dos suportes tradicionais de leitura. 


\title{
2 Carlos Drummond de Andrade: dos jornais às mídias
}

\begin{abstract}
A poesia fugiu dos livros, agora está nos jornais.
Os telegramas de Moscou repetem Homero.

Mas Homero é velho. Os telegramas cantam um mundo novo que nós, na escuridão, ignorávamos.
\end{abstract}

(ANDRADE, 1912, p.128)

A realidade das novas tecnologias digitais continua se impondo e demonstrando seu caráter indispensável para a comunicação no século XXI. A importância de coexistência das várias formas de comunicação nos afasta das vozes apocalípticas que, desde o século passado, previam o fim da literatura com a chegada da TV, do rádio e, contemporaneamente, da internet. O que se percebe é uma cena diversa, já que o texto literário ganhou novos suportes, se expandiu com a multimídia, passando, assim, a envolver cada vez mais leitores. É nesse contexto que examinamos o caminho percorrido pela obra drummondiana, conduzida, a princípio, pelas mãos do próprio escritor, passando em seguida por produtores, cineastas, radialistas até a chegada às redes sociais que se deu, em grande parte, pelos cliques de seus leitores apaixonados.

Após três décadas da morte de Carlos Drummond de Andrade, sua produção literária e sua biografia continuam despertando interesse de estudiosos, de uma nova geração de leitores e de consumidores de produtos culturais. Como consequência, observa-se a expansão dessa produção para as mídias tradicionais, o cinema, o teatro e a televisão. Ademais, inspirou a música popular brasileira e os trabalhos de nomes como Paulo Diniz, Milton Nascimento, Walter Franco, Belchior, José Miguel Wisnick, Moacyr Luz, entre outros. 
O cinema e a televisão são dois exemplos de meios de comunicação de massa que buscaram matéria-prima na obra drummondiana para levá-la ao grande público, exercendo o papel de agente divulgador do universo poético e de suas diversas possibilidades de representação. Nesse sentido, é possível citar o documentário Poeta das sete faces, do diretor Paulo Thiago, remetendo ao Poema de sete faces, publicado no livro Alguma poesia. Já $\mathrm{O}$ último poema, da diretora e roteirista Mirela Kruel, narra a relação entre Carlos Drummond e Helena Maria Balbinot Vicari, uma jovem estudante de Guaporé (RS), apresentando, entre outras curiosidades, a relação do poeta com o seu público leitor e a preocupação em responder a ele. Outras produções também demonstram a maleabilidade que a poética do escritor mineiro alcança na mídia audiovisual brasileira, como atesta o filme $\mathbf{O}$ padre e a moça, uma adaptação livre do poema $\mathrm{O}$ padre, a moça, da obra Lição de coisas. $O$ documentário $O$ amor natural traz poemas eróticos publicados após a morte do escritor, enquanto No caminho de Drummond é um ensaio documental sobre o escritor mineiro. $\mathrm{O}$ filme $\mathbf{O}$ vestido, uma adaptação do diretor Paulo Thiago do poema Caso do Vestido, foi selecionado para a mostra competitiva da $29^{\mathrm{a}}$ edição do Festival de Cinema Ibero-Americano de Huelva, na Espanha. Portanto, observa-se a partir desse movimento, não apenas a circulação da obra de Drummond por diversos meios de comunicação, mas também a ressignificação da sua obra entre leitores e espectadores.

Em 1921, Drummond publicou seus primeiros trabalhos no jornal Diário de Minas, e, nessa ocasião, já frequentava a vida literária de Belo Horizonte. Em 1929, deixa o Diário de Minas e passa a trabalhar no Minas Gerais, órgão oficial do estado, como auxiliar de redação e, pouco depois, redator, dessa maneira, sua 
entrada no serviço público se fez pela porta do denominado jornalismo cultural, atividade que desenvolveu durante anos, atuando em três âmbitos: no serviço público, sua principal fonte de renda, na publicação de poesias em edições raras com pequena tiragem e no jornalismo, escrevendo com assiduidade para diversos jornais de Belo Horizonte e do Rio de Janeiro. A relação de Drummond com o jornalismo reverbera ainda em sua produção poética, como ilustra o metapoema acerca da matériaprima de que se faz o jornal, ou seja, os fatos cotidianos:

\author{
Poema do jornal \\ O fato ainda não acabou de acontecer \\ e já a mão nervosa do repórter \\ o transforma em notícia. \\ O marido está matando a mulher. \\ A mulher ensanguentada grita. \\ Ladrões arrombam o cofre. \\ A polícia dissolve o meeting. \\ A pena escreve. \\ Vem da sala de linotipos a doce música mecânica \\ $[\ldots]$ \\ (ANDRADE, 2013 p. 41).
}

O poema foi publicado originalmente no jornal O Estado de Minas, de Belo Horizonte, em 30 de abril de 1930, desse modo, não apenas tematiza o jornal, mas o próprio jornal é o meio de divulgação, apontando para seu procedimento criativo e modo de circulação. Em Poema do jornal, é possível observar a rotina de trabalho, na qual os fatos ordinários do cotidiano são registrados e divulgados logo depois que ocorrem, numa tentativa de, no menor tempo possível, transformar o evento em registro. A rapidez em noticiar é um dos aspectos mais característicos do jornal, pois transmitir a novidade do dia antes que envelheça reflete a velocidade com que tudo acontece no 
jornal. Tal velocidade representa a vida que é absorvida na modernidade pela máquina de escrever, conduzida pela hábil mão do repórter. O elogio ao jornal, na forma de um poema, não significa tanto a possibilidade de um vínculo produtivo entre essas duas linguagens, mas, provavelmente, a aceitação pelo poeta do ritmo imposto pelos tempos modernos, cujo epicentro é a máquina, tornando-se o poema um canal para esse anseio pelo novo.

A atividade de Drummond na imprensa foi intensa e duradoura, além de simultânea à produção de livros de poemas, com uma temática moderna voltada para o cotidiano, o social, o autobiográfico e o histórico. $\mathrm{O}$ escritor mineiro ensaiou também uma carreira de contista com o livro Contos de aprendiz (1951), cujo título já antecipava que esse não seria um gênero tão fértil em sua escrita, talvez por isso Drummond não tenha escrito muitos contos ao longo de sua carreira. Contudo, outra forma literária, a crônica, próxima da linguagem jornalística, caracterizada pelos temas cotidianos, até certo ponto banais, marcaria definitivamente a produção do escritor e se tornaria um canal de comunicação mais direto com o público leitor. Naquela época, os escritores haviam percebido nesse gênero uma importante forma de comunicação com o grande público, formado praticamente por leitores de jornais que buscavam na crônica um texto leve entre as notícias sérias e ásperas do dia a dia. Além disso, a crônica é um formato que se adéqua perfeitamente ao espaço das colunas do jornal e ao ritmo frenético da vida na metrópole, tornando-se, pois, uma produção literária acessível ao público leitor.

A produção cronística do escritor mineiro é muito vasta e reúne mais de seis mil textos. A crônica sedimentou o estilo 
drummondiano, sarcástico, mordaz e irônico, encontrando nela sua melhor expressão ao longo de sua carreira literária e jornalística. A intensidade dessa produção coloca Drummond na posição de um dos maiores representantes da moderna crônica brasileira. No Jornal do Brasil (periódico no qual escrevia três vezes por semana, dos anos 1969 a 1984), Drummond assinou cerca de 2.300 textos, superando o volume de sua produção poética.

A crônica, por ser um gênero que circula em um suporte efêmero como é o jornal, assimilou o cotidiano e se tornou muito próxima da sociedade. Segundo Antonio Candido (1992), esse traço que se encaminha para o "literário" não livra esse tipo de discurso do consumo imediato de seu suporte, o jornal ou a revista, em princípio descartável: "Filha do jornal e da era da máquina, onde tudo acaba tão depressa, a crônica não foi feita originariamente para o livro, mas para essa publicação efêmera [...]" (CANDIDO, 1992, p. 14). Drummond chegou a confessar, em carta a Mário de Andrade, que considerava o jornalismo uma escola para a literatura e a literatura uma escola para o jornalismo:

O jornalismo é a escola de formação e de aperfeiçoamento para o escritor, isto é, para o indivíduo que sinta a compulsão de ser escritor. Ele ensina a concisão, a escolha das palavras, dá noção do tamanho do texto, que não pode ser nem muito curto nem muito espichado. Em suma, o jornalismo é uma escola de clareza de linguagem, que exige antes clareza de pensamento. E proporciona o treino diário, a aprendizagem continuamente verificada. Não admite preguiça, que é o mal do literato entregue a si mesmo. O texto precisa saltar do papel, não pode ser um texto qualquer. Há páginas de jornal que são dos mais belos textos literários. E o escritor dificilmente faria se não tivesse a obrigação jornalística. (apud FROTA; SANTIAGO, 2002, p. 349). 
No entanto, a alusão de Candido à efemeridade da crônica não a torna menor ou secundária em relação aos outros gêneros literários, já que a vinculação desta ao jornal tampouco a torna menos importante:

A crônica não é um "gênero maior". Não se imagina uma literatura feita de grandes cronistas, que lhe dessem o brilho universal dos grandes romancistas, dramaturgos e poetas. Nem se pensaria em atribuir o Prêmio Nobel a um cronista, por melhor que fosse. Portanto, parece mesmo que a crônica é um gênero menor. "Graças a Deus", - seria o caso de dizer, porque sendo assim ela fica perto de nós. (CANDIDO, 1992, p. 23).

Outro aspecto interessante entre a relação do jornal com a produção poética de Drummond é o fato de muitos de seus poemas terem sido publicados antes em jornais e somente depois em livro, prática relativamente comum até certa altura do jornalismo brasileiro. Essa ponte que o escritor estabeleceu com o jornalismo colabora para que a sua obra poética absorva a experiência intensa de proximidade com a realidade com que trabalha o jornalismo, como demonstrou o Poema do jornal.

$\mathrm{Na}$ atividade cotidiana de escrita no jornal, Drummond encontra espaço para estreitar os laços com o leitor; talvez isso explique o prazer que, de certa forma, o escritor revela quando comenta acerca de sua atividade jornalística:

- A que espécie de jornalismo você se refere: ao assinado, com pretensão estilística? - Ao jornalismo no duro, que vai pela noite adentro ou pelo dia afora, conforme a pressão da notícia. Jornalismo suado e sofrido, com algo de embriaguez, pela sensação de viver os acontecimentos mais alheios à nossa vida pessoal, vida que fica dependendo do fato, próximo ou distante, do imprevisto, do incontrolável, da corrente infinita de acontecimentos. [...] Sempre gostei de ver o sujeito às voltas com o fato, tendo de captá-lo e expô-lo no calor 
da hora. Transformar o fato em notícia, produzir essa notícia do modo mais objetivo, claro, marcante, só palavras essenciais. Ou interpretá-lo, analisá-lo de um ponto de vista que concilie a posição do jornal com o sentimento comum, construindo um pequeno edifício de razão que ajude o leitor a entender, a concluir por si mesmo: não é um jogo intelectual fascinante? $E$ renovado todo dia! Não há pausa. Não há dorzinha pessoal que possa impedi-lo. $\mathrm{O}$ fato não espera. O leitor não espera. Então você adquire o hábito de viver pelo fato, amigado com o fato. Você se sente infeliz se o fato escapou à sua percepção. (ANDRADE, 2003, p. 1221).

O jornalista Geneton Moraes Neto, ao entrevistar o poeta, questionou se "o jornalismo poderia ser literatura", ao que Drummond respondeu: "O jornalismo é uma forma de literatura. $\mathrm{Eu}$, pelo menos, convivi - e mil escritores conviveram - com uma forma de jornalismo que me parece muito afeiçoada à criação literária: a crônica [...]" (ANDRADE, 1987 apud MORAES NETO, 2007, p. 52). Assim, Drummond, entre crônicas e poemas, expunha suas ideias renovadoras e ia se firmando como escritor modernista, lançando mão do jornal, veículo da cultura impressa para divulgar textos do novo ideário literário e intelectual.

Ao ler atentamente a obra do escritor, pode-se depreender que as revistas foram fundamentais para a sua formação literária desde a infância. $\mathrm{O}$ acesso a elas fornecia, entre outras coisas, a possibilidade de ampliar seu universo, a partir da poesia, de gravuras, narrativas de aventura e de tudo o mais com que pudesse ter contato. Não por acaso sua escrita está permeada de referências ao leitor que o constituiu desde a infância. $\mathrm{O}$ vasto imaginário que Drummond construiu por meio da leitura das revistas foi estratégico não somente para sua formação leitora, mas também para sua formação de escritor, a exemplo do que ele próprio considerou como sua primeira emoção literária: As Aventuras de Robinson Crusoé, de Defoe. 
$\mathrm{O}$ contato com revistas mostrou-se fundamental para a produção do poeta, a exemplo de A Revista, periódico do grupo modernista mineiro, dirigido por Carlos Drummond de Andrade e Martins de Almeida. É necessário mencionar que, antes da publicação de Alguma Poesia, Drummond publicou em revistas vários dos poemas que integrariam seu primeiro volume de poesias, a exemplo do emblemático No meio do caminho, publicado na Revista de Antropofagia, de São Paulo, em julho de 1928, com edição de Oswald de Andrade; já na revista Verde, de Cataguazes, publicou o poema Quadrilha pela primeira vez, em novembro de 1927. Dessa maneira, as revistas artísticas se apresentaram como importantes meios de veiculação da produção literária brasileira do início do século XX. Além de Drummond, elas contaram com colaboradores que representaram a produção artístico-literária do movimento modernista, como Graça Aranha, Oswald de Andrade, Manuel Bandeira, Murilo Mendes, entre outros. Além disso, os principais manifestos modernistas foram publicados em revistas que funcionaram como porta-vozes dos diferentes grupos. Nelas eram veiculadas teorias sobre a arte moderna, trechos de contos, romances, poemas, além de eventos artísticos e outros temas de relevância para o Modernismo brasileiro.

Conforme dados divulgados pelo Projeto Memória: Drummond, testemunho da experiência humana (2011), nos anos 1950 e 1960, o escritor trabalhou em alguns programas de rádio. Na Rádio $\mathrm{MEC}$ realizou a série de palestras Quase memórias, em 1954; colaborou em Quadrante, em 1961, e criou o programa Cadeira de balanço, em 1963. Na Rádio Roquete Pinto, colaborou em Vozes da cidade, também em 1963. Nesses programas, o escritor levava literatura e arte para 
a audiência. Nesse mesmo período, vários poemas do escritor foram musicados e muitos transmitidos pelo rádio e outros foram gravados pelo poeta em discos de venda comercial. Dessa maneira, o escritor utilizou as mídias tradicionais disponíveis na época, em diferentes suportes, a fim de difundir a poesia para outros espaços, alcançando muitos ouvintes e ampliando as formas de circulação do texto literário, como esclarece em 1941, no depoimento "Para que serve o rádio?" quando vislumbrou nesse meio de comunicação um precioso instrumento educativo e de difusão da cultura. Isso significa que Drummond estava atento às novas formas de expressão da sociedade, a suas demandas e preferências, e, assim como outros escritores, demonstrou estar imbuído do desejo de alcançar e expandir novos públicos.

Pode-se então afirmar que o poeta cronista já extrapolava o impresso como suporte para seus textos, utilizando-se também do rádio para aproximar a literatura do público leitor, constituindo assim ouvintes de poesia. Esse meio de comunicação de massa era relativamente novo, tendo sido lançado oficialmente no Brasil no dia sete de setembro de 1922, na abertura da exposição comemorativa do centenário da Independência quando aconteceu a primeira transmissão radiofônica oficial no Rio de Janeiro (CASTRO, 2020). O rádio revolucionou a comunicação a distância, pois não se limitou a transmitir notícias ou campanhas políticas, mas funcionou também como divulgador da cultura literária.

A presença da poesia de Drummond por meio do sistema de difusão do rádio foi importante, mas a ideia de preservar sua obra para além do seu tempo também foi uma preocupação do escritor. Nesse sentido, a tendência memorialística do poeta o fazia registrar acontecimentos, elaborar listas e rotular experiências, 
como se classificasse o mundo para melhor compreendêlo. Assim, Drummond pensou o mundo, ordenando-o ou desordenando-o a partir das letras. Daí almejar a criação de um museu de literatura, indicando assim sua inclinação de arquivista, já expressa na maneira como organizava suas fotos, cartas, textos, desenhos. Drummond, mais de uma vez, em suas crônicas, manifestou o desejo de que no Brasil se fundasse um centro que tivesse como objetivo primordial a preservação da literatura brasileira, como registrou em 11 de julho de 1972:

Velha fantasia deste colunista - e digo fantasia porque continua dormindo no porão da irrealidade - é a criação de um museu de literatura. Temos museus de arte, história, ciências naturais, carpologia, caça e pesca, anatomia, patologia, imprensa, folclore, teatro, imagem e som, moedas, armas, índio, república... de literatura não temos [...]. Mas falta o órgão especializado, o museu vivo que preserve a tradição escrita brasileira, constante não só de papéis como de objetos relacionados com a criação e a vida dos escritores. É incalculável o que se perdeu, o que se perde por falta de tal órgão. Será que a ficção, a poesia e o ensaio de nossos escritores não merecem possuí-lo? O museu de letras, que recolhesse espécimes mais significativas, prestaria um bom serviço. (ANDRADE, 1972, p. 5)

Em 28 de dezembro de 1972, o sonho do escritor torna-se realidade com a constituição do Arquivo-Museu de Literatura (AMLB), por meio da Fundação Casa de Rui Barbosa, no Rio de Janeiro. No ano de 1994, foi implantado no AMLB o sistema de automação que, sem dúvida alguma, facilitou o acesso à informação. Drummond auxiliou os pesquisadores, selecionando 21 títulos e elaborando índices em folhas datilografadas que estão digitalizadas e acessíveis para consulta. 
Nesse percurso pela cultura impressa, pelo universo do audiovisual, é possível constatar que Drummond sempre se interessou por aproximar sua escrita de seu leitor e, para isso, transitou com desenvoltura e criatividade nas interfaces do mundo das letras. Mas o desejo de aproximação não se limita à relação do autor com o público, pois os admiradores de sua produção também têm realizado, ao longo do tempo, trabalhos que buscam aproximação com a vida e a obra do escritor.

\section{Drummond entre compartilhamentos e seguidores}

Na contemporaneidade, leitores e admiradores se apropriam da obra do poeta mineiro transportando-a para o ambiente virtual de sites, blogs e redes sociais, tornando sua produção ainda mais acessível e conhecida do grande público da internet, incluindose aí uma parcela significativa do público que não tem o hábito de ler em suportes impressos, como o livro.

As redes sociais na internet emergem das práticas de interação orientadas para a partilha e formação de grupos de interesses. Essas comunidades interativas provocaram uma migração de pessoas, produtos, ideias, comportamentos, imagens e textos para o ambiente virtual. Embora esse movimento seja real, isso, de forma alguma, significa que os outros suportes ou espaços tenham perdido sua importância, pois, neste momento, as mídias tradicionais e digitais, o impresso e o visual coexistem, ou seja, evidenciando que não é necessário desaparecer um meio para que o outro surja.

A mídia digital funciona como um canal de expressão, de visibilidade e de participação coletiva para escritores e para os leitores que têm a oportunidade de emitir as suas opiniões 
sobre o que leem (e, no caso dos escritores que escrevem nas plataformas digitais, de poder dialogar diretamente com aqueles que leem), circunstância que, há pouco tempo, seria difícil de se pensar, em virtude da comunicação entre o leitor e o escritor ter sido, ao longo de séculos, mediada pelas editoras. Desse modo, a presença da literatura e, particularmente, de poesia nas redes sociais só reitera a constatação de que a leitura pode ser realizada em distintos suportes. O que talvez exista de novo é a forma de interagir com o escrito, que, de certa forma, se distancia da interação com o impresso. Segundo Lévy (2003), as redes sociais na internet constituíram comunidades virtuais que produziram uma nova maneira de fazer sociedade. O fato é que a relação entre virtual e social rompeu com a barreira física do território, redefiniu a ideia de tempo e espaço e ampliou como nunca as possibilidades de interações, reverberando nos modos de se produzirem e consumirem o texto literário e os novos objetos de linguagem.

Entre os produtos culturais e literários que circulam na internet, encontram-se poemas que, em redes como Facebook e YouTube, são vistos e compartilhados inúmeras vezes. Facebook é uma mídia social e rede social virtual lançada em 4 de fevereiro de 2004 que se desenvolve a partir das interações humanas online, contando atualmente com mais de 2,27 bilhões de perfis. A partir disso, é possível inferir que essa rede social possibilitou o surgimento de uma nova forma de interação, na qual a posição individual muda de receptor passivo para a de produtor de conteúdo.

$\mathrm{Na}$ Imagem 1, é possível verificar que a página dedicada a Drummond, no Facebook, recebeu 275.024 "curtidas" e é "seguida" por 286.267 pessoas: 


\section{Imagem 1- Página do Facebook dedicada a Carlos Drum- mond de Andrade}

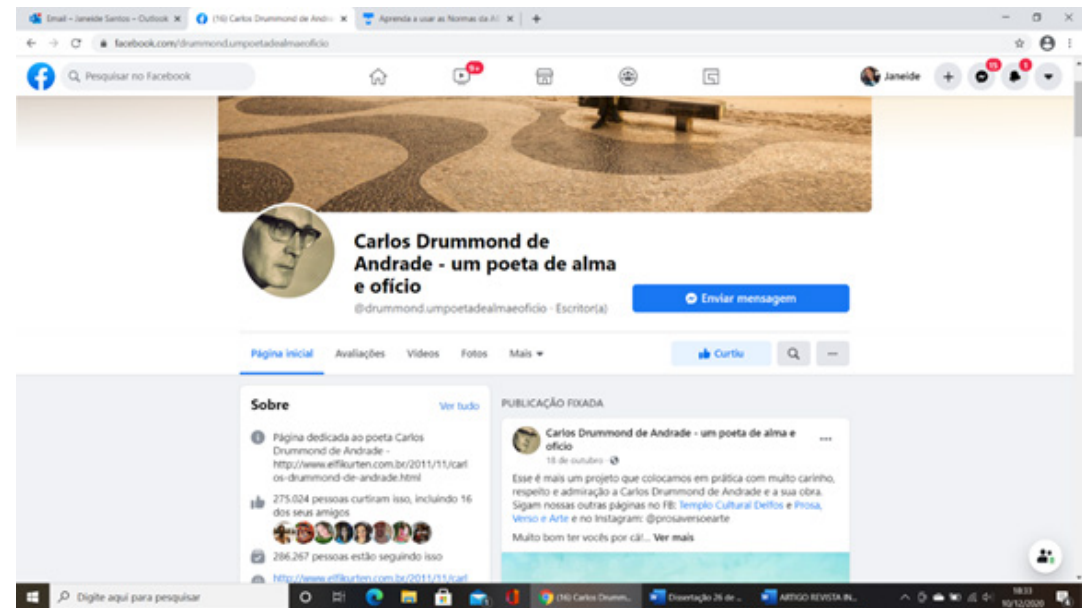

Fonte: Facebook, 2020.

A Imagem 2 demonstra como a produção de Drummond circula na plataforma YouTube. Para o vídeo intitulado Carlos Drummond de Andrade por ele mesmo (Poemas), no qual é possível apreciar o escritor declamando uma série de poemas, contam-se 567.355 visualizações, 10.000 likes e 402 comentários: 
Carlos Drummond de Andrade: da cultura impressa às mídias digitais

\section{Imagem 2 - Página do YouTube dedicada a Carlos Drum- mond de Andrade}

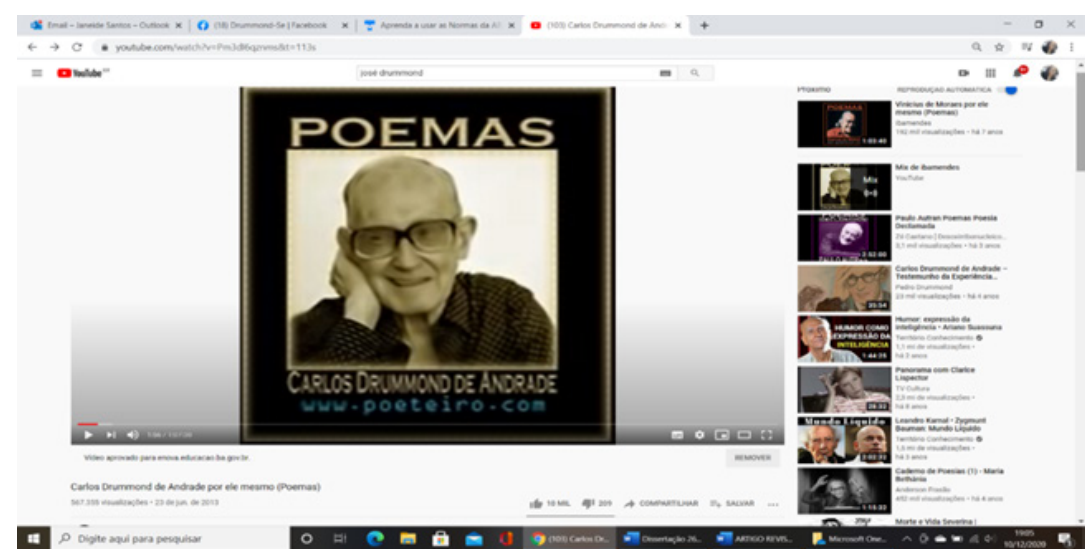

Fonte: YouTube, 2020

Na Imagem 3, observa-se que, ao pesquisar no YouTube a expressão "E agora José", trecho de um dos poemas mais conhecidos de Carlos Drummond de Andrade, obtém-se um resultado muito expressivo, que apresenta uma série de conteúdos produzidos a partir do título desse poema. Esses conteúdos vão de músicas a vídeos de animações, passando por pessoas declamando os textos. Além da circulação do conteúdo poético nas mídias, deve-se observar a participação do receptor nesse processo, que vai do consumo até a própria produção desses e de outros produtos, passando pela interatividade dos comentários. 


\section{Imagem 3 - Resultado de busca no YouTube pela expressão "E agora José"}

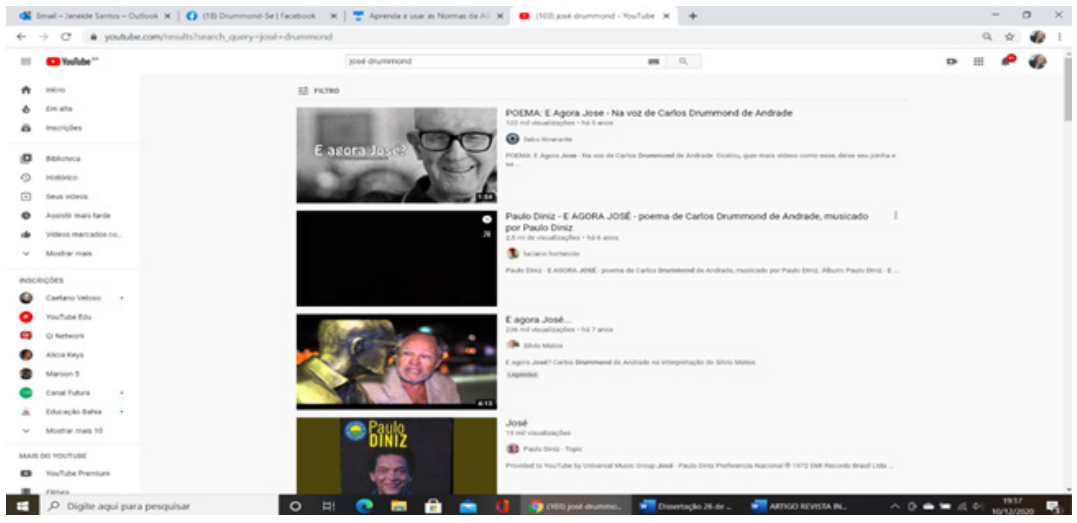

Fonte: YouTube, 2020

O YouTube, fundado em fevereiro de 2005, é uma plataforma e um agregador de conteúdo produzido pelo usuário, configurando-se como o mais importante site de difusão e de compartilhamento de vídeos. Por ser um site de cultura participativa é necessário levar em consideração o contexto da cultura digital marcado pela vida em rede, pela versatilidade, por encontros de diferenças culturais e pela ideia de colaboração, pois, segundo Lévy (1999), as novas formas de comunicação formam "processos abertos de colaboração".

Alguns poemas de Drummond ficaram marcados na memória do grande público, sendo um exemplo disso, José, escrito em 1942 e publicado pela Editora José Olympio na coletânea Poesias. Vários motivos fazem desse poema uma marca na produção drummondiana: a visão pessimista do cotidiano, a solidão do homem, sua falta de espaço e até a profunda angústia pela vida: 
E agora, José? /A festa acabou, /a luz apagou, /o povo sumiu, /a noite esfriou, /e agora, José? /e agora, Você? /Você que é sem nome, /que zomba dos outros, /Você que faz versos, /que ama, protesta? / e agora, José?/ Está sem mulher,/ está sem discurso,/ está sem carinho,/ já não pode beber,/ já não pode fumar,/ cuspir já não pode,/ a noite esfriou,/ o dia não veio,/ o bonde não veio,/ o riso não veio,/ não veio a utopia/ e tudo acabou/ e tudo fugiu/ e tudo mofou,/ e agora, José?/ E agora, José?/ Sua doce palavra,/ seu instante de febre,/ sua gula e jejum,/ sua biblioteca,/ sua lavra de ouro,/ seu terno de vidro,/ sua incoerência,/ seu ódio - e agora? [...] você marcha, José!/ José, para onde? (ANDRADE, 1942).

Outra característica desse texto é que ele remete o leitor a diversas interpretações. Tem-se a impressão de que qualquer pessoa pode ser José, esse personagem que desfruta de uma fortuita alegria e felicidade, mas que as perde, pois "a festa acabou". Em uma pesquisa rápida no Google, no dia 28 de novembro de 2020, apareceram aproximadamente 2.410.000 resultados (0,45 segundos) para a expressão "José de Carlos Drummond de Andrade", um exemplo de uma propagação quase viral desse poema na internet e do papel dos produtores de conteúdo para a rede.

É importante ressaltar que a internet surgiu como mais uma possibilidade de interação entre a literatura e o leitor, sobretudo porque os leitores continuam lendo no impresso ou assistindo a produções audiovisuais adaptadas de obras literárias. Essa aproximação se dá em função das muitas possibilidades e links de que a internet dispõe, o que facilita, de certa forma, o acesso ao texto, como aponta Munari, Bocchese e Aguiar:

Quando a literatura produzida em livro é transferida para a internet, tornando-a seu suporte, ela costuma figurar em websites voltados especificamente para o mundo das letras: páginas de instituições, de editoras, 
dos próprios autores, revistas eletrônicas, e ainda em portais de comunicação, como os jornais digitais. Muito frequentemente ela aparece em blogs e redes sociais, em fragmentos, recriações, comparações, geralmente com comentários, acréscimos, recortes, manipulações digitais. (MUNARI; BOCCHESE; AGUIAR, 2011, p. 4).

Pode-se constatar que a transição do impresso para o digital leva o texto ao encontro de novos leitores, além de expandir suas formas por meio de (re)criações realizadas pelos internautas. Estudos recentes apontam que há uma mudança na experiência de leitura, ou seja, mudam-se os suportes, mudam-se as formas de ler o mesmo texto. Chartier aponta que um mesmo texto, apresentado em diferentes suportes, se traduz em diferentes significados ao leitor:

A forma do objeto escrito dirige sempre o sentido que os leitores podem dar a aquilo que leem. Ler um artigo em um banco de dados eletrônico, sem saber nada da revista na qual foi publicado, nem dos artigos que o acompanham, e ler o "mesmo" artigo no número da revista na qual apareceu, não é a mesma experiência. $\mathrm{O}$ sentido que o leitor constrói, no segundo caso, depende de elementos que não estão presentes no próprio artigo, mas que dependem do conjunto dos textos reunidos em um mesmo número e do projeto intelectual e editorial da revista ou jornal. (CHARTIER, 1998, p. 128).

Desse modo é possível inferir que, quando um texto transita entre diversos meios, inclusive pelos meios digitais e computacionais, leva consigo não apenas várias possibilidades de leitura, mas também, de interpretações. Pode-se afirmar ainda que o leitor adquire novas formas de se relacionar com a leitura, já que muitos leitores dos suportes digitais formam e/ou participam de comunidades de leitores, onde são promovidas discussões e 
emitidas opiniões sobre os textos lidos. Esse modo de leitura, a que podemos emprestar o nome de leitura compartilhada, distancia-se da leitura silenciosa e, ao mesmo tempo, solitária, ao instaurar um ambiente de interação.

O leitor que se utiliza do digital, o webleitor, não se contenta em somente ler os textos poéticos, mas deseja compartilhá-los com outros seguidores das redes sociais, interagindo com os posts, curtindo e comentando, promovendo uma propagação midiática a partir da sua participação e envolvimento com seu objeto de desejo. Esses leitores postam imagens que julgam interpretar ou explicar determinados poemas, produzem vídeos com declamação de poemas e com comentários sobre a vida e a obra dos escritores favoritos - em muitos casos há uma postura que se assemelha à de fãs e não apenas de leitores. Esse comportamento ilustra a cultura participativa, conceito que designa a forma como os consumidores contemporâneos, desde a popularização da internet, têm se distanciado da condição de receptores passivos ao produzir conhecimento e disseminar informações e ideias:

A expressão cultura participativa contrasta com noções mais antigas sobre a passividade dos espectadores dos meios de comunicação. Em vez de falar sobre produtores e consumidores de mídia como ocupantes de papéis separados, podemos agora considerá-los como participantes interagindo de acordo com um novo conjunto de regras, que nenhum de nós entende por completo [...] (JENKINS, 2009, p. 4).

Segundo Henry Jenkins (2009), a sociedade está cada vez mais íntima das tecnologias e da internet, repleta de fãs, que são os que não apenas consomem certa informação, mas também produzem e trocam conhecimento ao redor do mundo. 
Nesse sentido, a poesia de Drummond seduz muitos leitores devido ao uso da ironia, do humor, além de temas voltados para o cotidiano, revitalizando assim sua produção poética por meio de leitores internautas que se veem representados nesses elementos, o que fica claro quando se observam as postagens nas redes sociais.

Ao usar a ferramenta "busca" no Facebook, é possível encontrar inúmeras páginas, comunidades e postagens de poemas de Drummond que são organizadas por uma verdadeira legião de fãs incansáveis em publicar diariamente fragmentos de textos do poeta, ou apenas em compartilhar ou dar um like em posts disponibilizados por outros seguidores. Esses sujeitos encontram nas redes sociais um espaço autônomo de apresentação e discussão da sua maneira de compreender e avaliar uma determinada obra, registrando suas leituras, discutindo com seus pares e ampliando o debate antes restrito a especialistas.

Os processos de leitura, recepção, produção e circulação de conteúdos culturais na internet se dão mediante diferentes atores. Alguns deles tornam-se, além de consumidores, produtores de conteúdo, o que demonstra que o cenário midiático é cada vez mais demarcado pela acessibilidade e liberdade. Tudo isso passa pela cultura participativa a partir da disseminação de conteúdos de diversas origens, que se entrelaçam nas comunidades de fãs que produzem sites, blogs e fanpages dedicados a Drummond.

Desse modo, quando tratamos de poesia, que teve sua provável morte anunciada desde a modernidade, a sua recepção pelos webleitores pode significar a conquista de novos leitores e de novas leituras. Portanto, é possível afirmar que a leitura compartilhada de poesia nos meios digitais não é banalização ou facilitação, mas atualização do que ela tem de mais essencial, 
o público leitor, além do fenômeno da comunidade de fãs que promove também a leitura criativa de poemas.

\section{Considerações finais}

Drummond foi um homem do jornal, das revistas, dos acervos, das bibliotecas, do rádio, do cinema e da TV. Contemporaneamente, a obra poética do escritor mineiro transita da cultura impressa às infovias da internet, alcançando públicos dos mais variados: sendo lida em diversos meios, ganhou a forma de música, filmes e documentários. Seus versos continuam sendo frequentemente parodiados, outros foram popularizados em expressões como "E agora, José?". A relação do leitor com a obra continua gerando produtos que circulam livremente no mundo digital, mas, se o leitor é mais tradicional, também encontrará dezenas de livros de poesia e de prosa que continuam a ser editados e disponibilizados em livrarias e bibliotecas.

A movência do texto poético dos livros para os suportes digitais é promovida por leitores, artistas, editoras, profissionais de rádio e TV, que integram as diversas mídias disponíveis para favorecer esse movimento que faz o texto e seus autores circularem por diversos locais de "leitura", atraindo, consequentemente, leitores veteranos e os recém-chegados ao mundo da literatura que circulam por espaços diversos a fim de vivenciarem as suas experiências com o texto. A presença de leitores e fãs participativos no ambiente virtual é um acontecimento inarredável, já que a midiatização cultural e social é uma realidade que cada vez mais ocupará as relações humanas, inclusive a relação entre o ser humano e suas criações culturais, como é o caso da produção poética. 
Drummond percorreu, evidenciou e visibilizou com perspicácia as nuances de sua produção literária. Embora tenha sido um crítico da modernidade mecanizada, logo depreendeu que a tecnologia deveria mediar e compartilhar a arte e, por isso mesmo, lançou mão dos meios de comunicação de massa disponíveis à época para divulgar a sua produção e convidar o grande público a conhecer mais de perto a literatura, pois o que o poeta mineiro sempre quis foi popularizar sua produção para seu público, o que, sem dúvida, conseguiu e, atualmente, vem conseguindo por meio das leituras, interações e recriações de seus leitores, espectadores e internautas contemporâneos.

\section{Referências}

ANDRADE, Carlos Drummond de. José. In: ANDRADE, Carlos Drummond de. Poesias. Rio de Janeiro: José Olympio, 1942.

ANDRADE, Carlos Drummond de. Museu: fantasia? Jornal do Brasil, Caderno B, p.5, 11 de julho de 1972. Disponível em: https://news.google.com/newspapers?nid=0qX8s2k1IRwC\&dat $=19720711 \&$ printsec $=$ frontpage \&hl=pt-BR. Acesso em: 04 jan. 2022.

ANDRADE, Carlos Drummond de. Sentimento do mundo. 5. ed. São Paulo: Record, 1998.

ANDRADE, Carlos Drummond de. Corpo. Rio de Janeiro: Record, 2002.

ANDRADE, Carlos Drummond de. Autobiografia para uma revista. Confissões de Minas (1944). In: ANDRADE, Carlos Drummond de. Prosa Seleta. Nova Aguilar, 2003.

ANDRADE, Carlos Drummond de. Poesia Completa. Rio de 
Janeiro: Nova Aguilar, 2006.

ANDRADE, Carlos Drummond de. José. Posfácio Júlio Castañon Guimarães. São Paulo: Companhia das Letras, 2012.

ANDRADE, Carlos Drummond de. Alguma poesia. Posfácio Eucanaã Ferraz. São Paulo: Companhia da Letras, 2013.

CANAVILHAS, João Messias. Webjornalismo: considerações gerais sobre jornalismo na web. 2001.

CANDIDO, Antonio. A vida ao rés-do-chão. In: A crônica: o gênero, sua fixação e sua transformação no Brasil. Campinas: Ed. UNICAMP; Rio de Janeiro: Fundação Casa de Rui Barbosa, 1992.

CASTRO, José de Almeida. História do Rádio no Brasil. Disponível em: http://www.abert.org.br. Acesso em: 21 mar. 2020.

CHARTIER, Roger. A aventura do livro: do leitor ao navegador. Conversações com Jean Lebrun. Tradução de Reginaldo Carmello Corrêa de Moraes. São Paulo: Imprensa Oficial/ Ed.UNESP, 1998.

Facebook. Disponível em: https://www.facebook.com/ drummond.umpoetadealmaeoficio. Acesso em: 10 dez. 2020

FROTA, Lélia Coelho; SANTIAGO, Silviano. Carlos e Mário: correspondência de Carlos Drummond de Andrade e Mário de Andrade. Rio de Janeiro: Bem-te-vi Produções Literárias, 2002.

YouTube. Disponível em: <https://www.youtube.com/ watch? $\mathrm{v}=$ Pm3dI6qznms\&t=113s $>$. Acesso em: $10 \mathrm{dez} .2020$

YouTube. Disponível em: <https://www.youtube.com/ results? search_query=jos $\% \mathrm{C} 3 \% \mathrm{~A} 9+$ drummond $>$. Acesso em: 10 dez. 2020.

JENKINS, Henry. Cultura da convergência. 2. ed. Tradução de Susana Alexandria São Paulo: Aleph, 2009.

JENKINS, Henry. Invasores do texto: fãs e cultura participativa. Tradução de Érico Assis. Nova Iguaçu/Rio de Janeiro: Marsupial, 
2015.

LÉVY, P. Cibercultura. Tradução de Carlos Irineu da Costa. São Paulo: Editora 34, 1999

LÉVY, Pierre. A inteligência coletiva: por uma antropologia do ciberespaço. 4. ed. Tradução São Paulo: Loyola, 2003.

MUNARI, Ana Cláudia; BOCCHESE, Jocelyne; AGUIAR, Vera Teixeira de. Literatura e internet. In: Semana de Letras, 9., 2011, Porto Alegre. 70 Anos: A FALE FALA. Anais [...] Porto Alegre: EDIPUCRS, 2011. Disponível em: http://ebooks. pucrs.br/edipucrs/anais/XISemanaDeLetras/pdf/anamunari.pdf. Acesso em: 30 jan. 2019.

NETO, Geneton Moraes. Dossiê Drummond. São Paulo: Globo, 2007.

SPALDING, Marcelo. Alice do livro impresso ao e-book: adaptação de Alice no país das maravilhas e de através do espelho para Ipad. Porto Alegre: 2012.

STEINER, George. Linguagem e silêncio: ensaios sobre a crise da palavra. Tradução de Gilda Stuart e Felipe Rajabally. São Paulo: Companhia das Letras, 2002

RODY, Verinha; PONTO, Bira do. Carnaval de 1987: No reino das palavras, Carlos Drummond de Andrade. Rio de Janeiro: Galeria do samba, 2022. Disponível em: http://www. galeriadosamba.com.br/escolas-de-samba/estacao-primeira-demangueira/1987/. Acesso em: 20 nov. 2020. 